\title{
Hinterland Intermodal Freight Flow Optimization for Ports Competition Evidence of West Africa ECOWAS Region
}

\author{
Brou Mathias Allate \\ School of Economy and Management, Shanghai Maritime University, Shanghai, China \\ Email: abromat@yahoo.fr
}

How to cite this paper: Allate, B.M. (2019) Hinterland Intermodal Freight Flow Optimization for Ports Competition Evidence of West Africa ECOWAS Region. Open Journal of Applied Sciences, 9, 215-229. https://doi.org/10.4236/ojapps.2019.94018

Received: December 6, 2018

Accepted: April 20, 2019

Published: April 23, 2019

Copyright $\odot 2019$ by author(s) and Scientific Research Publishing Inc. This work is licensed under the Creative Commons Attribution International License (CC BY 4.0).

http://creativecommons.org/licenses/by/4.0/

\begin{abstract}
Major problem considered in this study was the intermodal routing problem of regional freight transportation in West Africa ECOWAS (Economic Community Of West Africa States), which can be defined as the problem of determining the freight flow quantity, the transportation mode in each transit corridor while satisfying the freight demand at each West Africa transit country (Mali, Burkina Faso and Niger). The objective was to minimize in land transportation costs. In order to solve optimally and represent the problem, this research employed a linear programming model. The model was solved using Lingo Mathematic Application. The model results showed that port oriented freight logistics in west Africa ECOWAS region do not flow along optimal path and such incur longer time and higher logistics cost than is geographically necessary.
\end{abstract}

\section{Keywords}

Port Hinterland, Port Competition, Intermodal Transport Optimization, West Africa, Lingo Language

\section{Introduction}

ECOWAS (Economic Community Of West Africa States) is a sub-group comprising fifteen (15) states (Figure 1) which are divided into two groups: coastal and landlocked countries

The region has twelve (12) Coastal States, each costal state has at least one port. However, the major ports serve a common hinterland, including three landlocked countries, Niger, Mali and Burkina Faso, and have to operate in a highly competitive environment. 


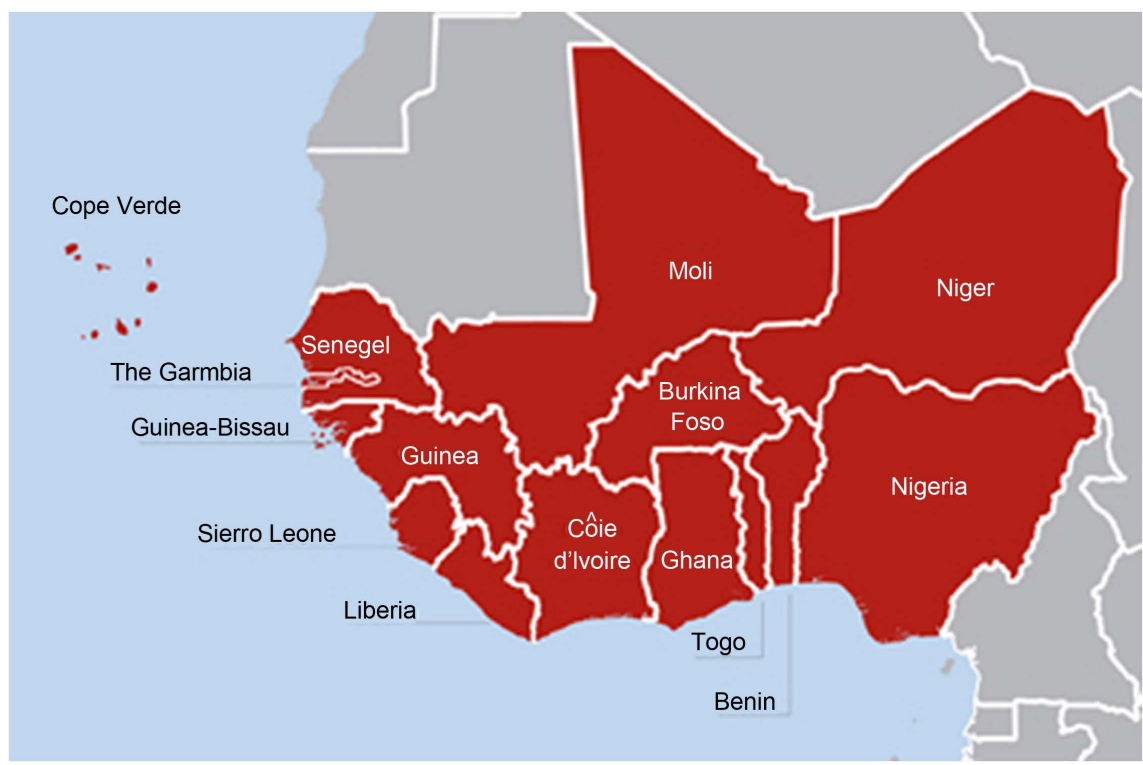

Figure 1. West Africa ECOWAS region members countries. Source: Google map.

These ports have quasi monopolies on their home country markets but compete for transit cargo to the three landlocked countries (LLC), and transshipment traffic to other ports.

Importations and exportations from or to those landlocked countries are majority through Cotonou, Abidjan, Tema, Senegal and Lome ports with are not only the gateways for landlocked countries but also the mains transit ports in the region.

The steady growth in cargo throughput through ports in developing countries and in West Africa in particular coupled with infrastructural and regulatory constraints has strained the entire regional logistics networks. This has resulted into congestion, high dwell time and higher logistics cost which in turn, limit competitive ability of region in global economy. Even through, the negative economic impact of inefficient costly logistics system is well recognized and documented. The region still endures limited ties between freight flow planning and economic development. From that reason, we recognize the need to fully integrate freight flow strategies into the broader economics and development models. Such integration strategies require quick and reliable tools for performing freight flow analysis.

As such, this research work undertook to make the system-wide freight flow analysis to investigate measure for improving the regional logistic network by focusing on intermodal transport optimization in West Africa ECOWAS region, which can be defined as the problem of determining the freight flow quantity, the transportation mode in each transit corridor while satisfying the freight demand at each West Africa transit country. The objective was to minimize inland transportation costs. In order to solve optimally and represent the problem, this research employed a linear programming model. The model was solved using Lingo Mathematic Language. 
The idea of this work was motivated by the need to address the problem of high logistics costs facing West Africa Economic and Monetary Union (ECOWAS) countries and others developing countries. In recognition of the fact economic advantage could be attained by embracing optimized freight flow.

Embracing the concept of inter-modality in West Africa offers an opportunity to mitigate high transport and logistics costs through improved hinterland flows of cargoes in an efficient and environmentally friendly manner.

\section{Literature Review}

\subsection{Freight Flow Optimization and Ports Competition}

According to [1] ports compete not only on the sea-side (e.g. through terminal investments, increase in terminal efficiency, maritime service connectivity) but also on the land-side (e.g. through logistics chain, advanced IT services, door-todoor connectivity).

On this issue, several studies [2] [3] recently pointed out the increasing importance of the connectivity at both quality and quantity level between the port and its own hinterland in order to be competitive in the modern maritime service structure.

The competitiveness of a seaport depends on the extent the cargo handled in the port can reach its hinterland destination [1]. The importance of hinterland connections has been recognized as one of the most critical issues in port competitiveness and development in most ports around the world.

Moreover [4] and [5] try to elaborate optimal model to connect ports with their respective hinterlands, [6] re-define ports as part of supply chains in which the hinterland connectivity appear as key competitive factor.

\subsection{Intermodal Transport Optimization}

Logistics network optimization is recognized as the most comprehension strategic decision tool for long term supply chain efficiency [7] [8] [9]. In an abstract terms, networks are represented by nodes that are connected by link or arcs. In this context nodes refer to e.g. port, terminals, inland terminal and cross sections on the other hand links or arc stand for roads, railway tracks or waterways [10] [11]. Additionally, a route consists of a sequence of nodes and links with a starting and ending port. In this regard network optimization models seek to apply mathematical formulation and algorithms to solve a given network flow.

The network flow problem could be such as solving shortest path problem, maximum flow problem, minimum cost flow problem or the assignment problem [12]. The optimization objective may include minimizing cost or time of the flow or maximizing the quantity of the flow through the network [8] and [10]. As indicated by [13], application of operations research methods in intermodal freight transportation is still limited. Application of operations research techniques like optimization in overall container supply chain is discouraged by the inherent complexity with the global container supply chains [14]. 
In solving optimization problem different approaches are employed. [15] developed a linear optimization model for containerized imports into the United States but focused solely on rail transport for access to respective hinterlands in USA. [7], [16] and [17] concentrated on road trucking for inland transport from port using non-linear models. [11] proposed Network Simplex method for solving the Minimum Cost Network Flow. [18] developed a methodology to make linear some nonlinear constraints thus reducing the complexity of optimization problem. Benders decomposition, Mixed Integer Programming (MIP) and Network Simplex Algorithm have been used to solve network problems including capacitated facility location network design problems based on CPLEX MIP solver [10] [11] [19] Intermodal network study received new thrust from [14] who employed Geographic Information System (GIS) for validation of mode sequences and route selection which results in optimal routing of freight.

Very few of the above approaches model freight flows in intermodal networks involving road, railways. Likewise, the potential of freight transportation flow optimization in West Africa remains largely unexplored. Noted deficient regarding freight transport studies make freight flow optimization in intermodal network an interesting area of research. The above identified gap regarding minimization of logistics cost through flow optimization was great motivation for this study and the gap was filled by introducing the Hinterland Intermodal Freight Transportation Model based on LINGO Mathematical Modeling Language.

\section{Research Methods}

This task includes finding details quantities freight (Tons) to be shipped from seaport, the transportation mode choice along each link (rail, rail or rail and road) and the detailed routing of freight from port to final destination.

The study focused on container import flows through the majors West transit gateways of Cotonou (Benin), Lome (Togo), Tema (Ghana), Abidjan (Cote d'Ivoire) and Dakar port (Senegal).

These countries use the port of Cotonou, Lome, Tema, Abidjan and Dakar as their main maritime gateways. Importations and Exports from and/ to the landlocked countries (Mali, Burkina Faso and Niger) are majority through those port.

The model evaluates the flow along 15 regional transit corridors. A graphical depiction of the above freight network made up of seaports, roads and rail corridors for inland transportation; transshipment nodes; cargo centers to final transit points is shown in Figure 2.

The primary source of this data has being port annual reports, the port annual review and also statistics collected from Port Management Association of West \& Central Africa (PMAWCA) based on 2015 statistics. Figure 3 described the transit import volume (tons) through the West Africa main gateways to West Africa landlocked countries (WALLC). 


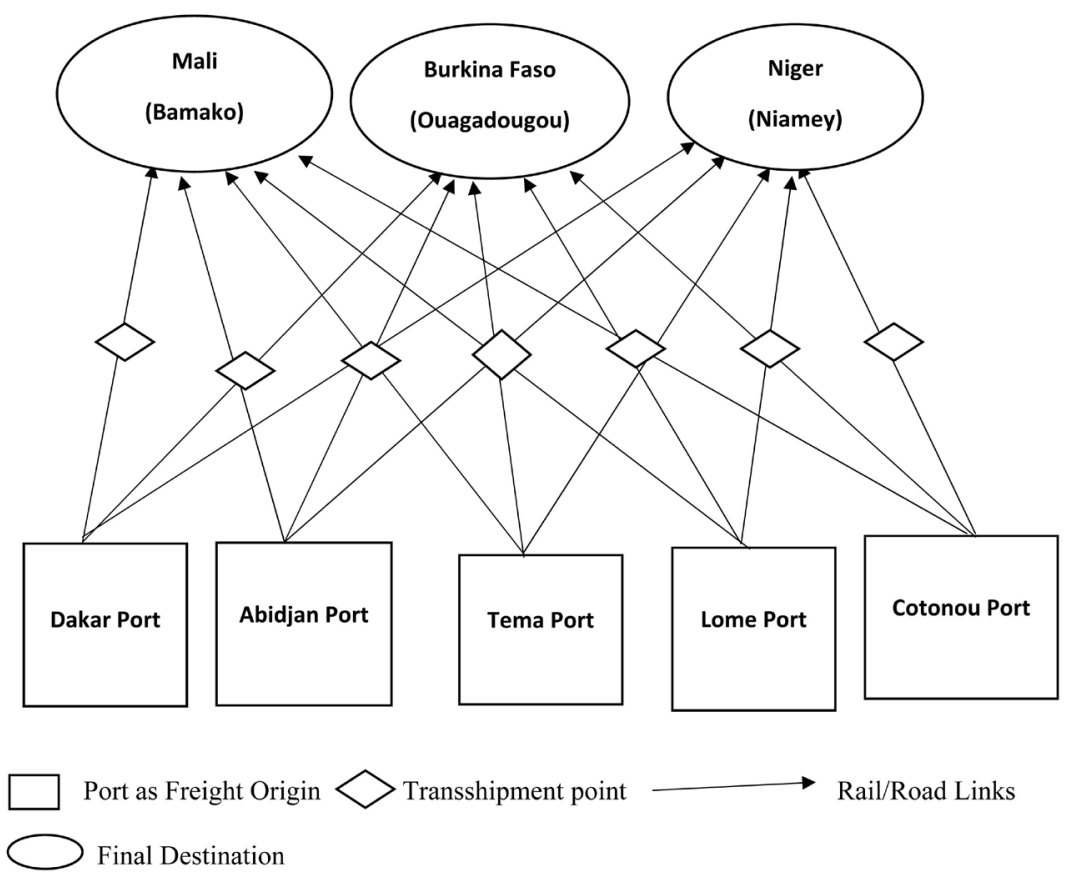

Figure 2. West Africa intermodal transport network description. Source: Author.

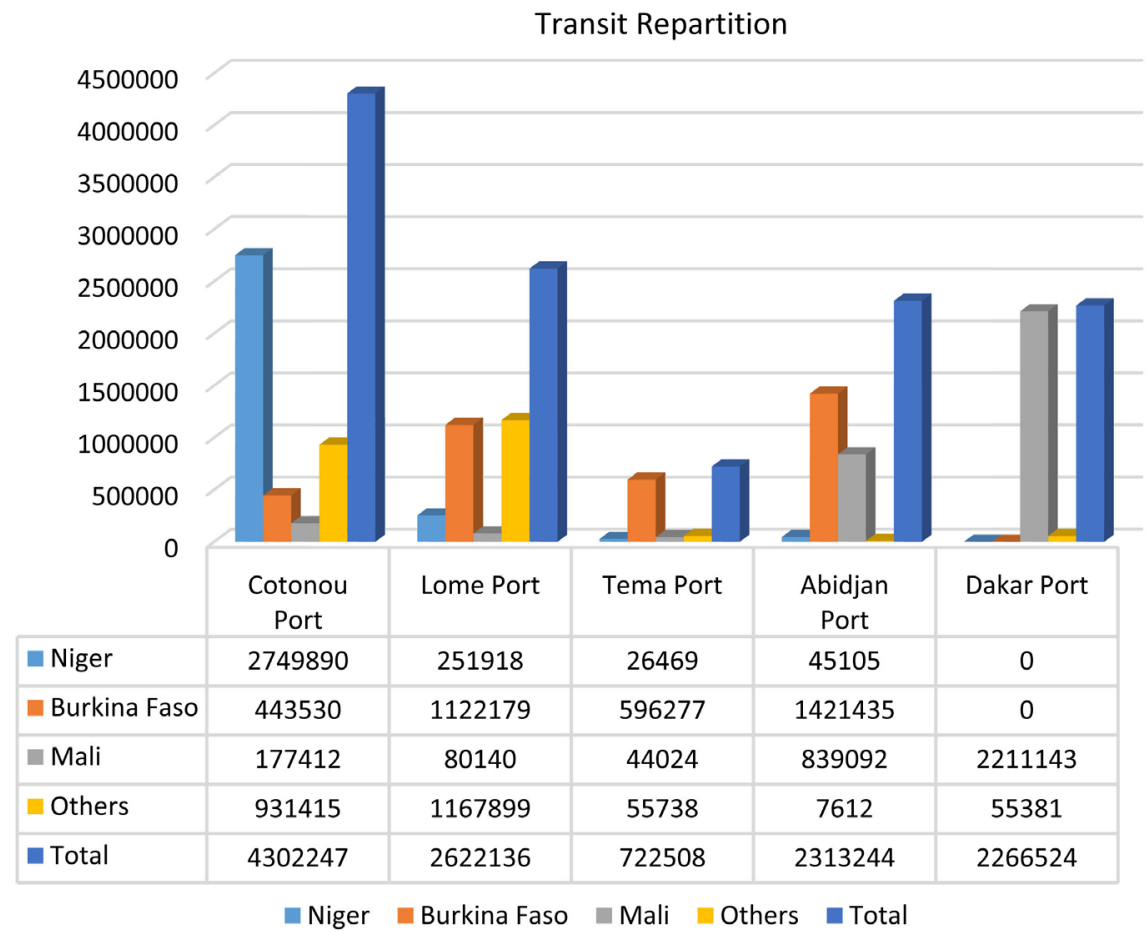

Figure 3. Transit throughout repartition by gateway to WALLC based on 2015 statistic. Source: Author.

\subsection{Mathematical Formulation}

The model represents an intermodal logistics network, representing the physical infrastructure of the system covering port, road and railway. Available operational function executed by the model involves: 
1) An itinerary for freight flow from port along the service path in a network used to move part of the total demand to the designated final transit destination.

2) Mode, which represent a specific or combination of transport mode (e.g. rail and truck)

Therefore, an intermodal logistics network optimization model for West Africa ECOWAS region freight imports flow was formulated as a minimum cost flow problem.

\subsubsection{Model Parameters}

I: set of port of served West Africa landlocked countries.

J: set of landlocked countries served by ports

$N$ : Number of transit as cargo centers serves by West Africa ECOWAS ports

$D_{i}$ : Total freight demand (Tons) at West Africa Landlocked transit country I, $d \in N$

$c^{\text {road }}($ Cotonou $)$ : Road link transport cost from Cotonou port to transit country

$c^{\text {road }}$ (Lome): Road link transport cost from Lome port to transit country $c^{\text {road }}($ Tema $)$ : Road link transport cost from Tema port to transit country $c^{\text {road }}$ (Abidjan) : Road link transport cost from Abidjan port to transit country $c^{\text {road }}$ (Dakar) : Road link transport cost from Dakar port to transit country $c^{\text {rail }}$ (Cotonou) : Rail link transport cost from Cotonou port to transit country $c^{\text {rail }}$ (Lome) : Rail link transport cost from Cotonou port to transit country $c^{\text {rail }}$ (Abidjan) : Rail link transport cost from Abidjan port to transit country $c^{\text {rail }}$ (Dakar): Rail link transport cost from Dakar port to transit country imp $_{i}$ (Cotonou) : Quantity (tons) of freight in transit at Cotonou port $\operatorname{imp}_{i}$ (Lome): Quantity (tons) of freight in transit at Lome port $\operatorname{imp}_{i}($ Tema ): Quantity (tons) of freight in transit at Tema port $\operatorname{imp}_{i}$ (Abidjan) : Quantity (tons) of freight in transit at Abidjan port $\operatorname{imp}_{i}($ Dakar) : Quantity (tons) of freight in transit at Dakar port

\subsubsection{Decision Variables}

$x_{1}$ : Quantity of freight (Tons) transported from Dakar port by both railway and highway to transit country $(j)$

$x_{2}$ : Quantity of freight (Tons) transported from Abidjan port by both railway and highway to transit country $(j)$

$x_{3}$ : Quantity of freight (Tons) transported from Tema port by highway to transit country $(j)$

$x_{4}$ : Quantity of freight (Tons) transported from Lome port by railway or/and by highway to transit country $(j)$

$x_{5}$ : Quantity of freight (Tons) transported from Cotonou port by railway or/and by highway to transit country $(j)$

\subsubsection{Objective Function and Constraints}

Minimize total logistic cost: 


$$
\begin{aligned}
& \sum \sum x_{1}\left(c^{\text {road }}+c^{\text {rail }}\right)+\sum \sum x_{2}\left(c^{\text {road }}+c^{\text {rail }}\right)+\sum \sum x_{3}\left(c^{\text {road }}+c^{\text {road }}\right) \\
& +\sum \sum x_{4}\left(c^{\text {road }}+c^{\text {rail }}\right)+\sum \sum x_{5}\left(c^{\text {road }}+c^{\text {rail }}\right)
\end{aligned}
$$

The objective function is to minimize the total transport cost of freight conveyance from ports to respective transit destination along two modes of transport namely highway and railway.

The first term evaluates the cost component incurred in trucking container (road) and logistics cost incurred in haulage of containers by railways from Cotonou port to final transit country destination.

The second term also evaluates the cost component incurred in trucking container (road) and logistics cost incurred in haulage of containers by railways from Lome port to final transit destination.

The third term evaluates the cost component incurred in trucking container (road) from Tema port to final transit destination.

The fourth term evaluates the cost component incurred in trucking container (road) and/or logistics cost incurred in haulage of containers by railways from Abidjan port to final transit destination.

The fifth term evaluates the cost component incurred in trucking container (road) and/or logistics cost incurred in haulage of containers by railways from Dakar port to final transit destination.

Logistics cost in this model is allocated for each flow arc and includes intermodal terminal handling costs were applicable, as well as freight costs.

Subject to:

$$
\begin{aligned}
\sum_{i=1}^{i=5} \sum x_{i} \leq & \sum \operatorname{imp}_{i}(\text { Cotonou })+\sum \text { imp }_{i}(\text { Lome })+\sum \text { imp }_{i}(\text { Tema }) \\
& +\sum \operatorname{imp}_{i}(\text { Abidjan })+\sum \operatorname{imp}_{i}(\text { Dakar })
\end{aligned}
$$

Constraint (2) ensures that the total transit freight quantity (Tons) from main gateways to final transit countries under consideration in this study by trucks and/or railway mode cannot exceed the combined transit imported throughput of respective ports. The left term of equation

Represents the quantity of freight hauled by railway or/and highway from Cotonou, Lome, Tema, Abidjan and Dakar ports to final transit countries under consideration in the study (Mali, Burkina Faso and Mali).

$$
\sum \sum x_{1}+\sum \sum x_{2}+\sum \sum x_{3}+\sum \sum x_{4}+\sum \sum x_{5} \geq \sum D_{i}
$$

Constraint (3) ensures that the total demand quantity of freight (Tons) at transit country under consideration in this study do not exceed the combined quantity of transit freight imported from west Africa main gateways of ports Cotonou, Lome, Tema, Abidjan and Dakar ports.

$$
x_{1}, x_{2}, x_{3}, x_{4}, x_{5} \geq 0
$$

Constraint (4) is non-negativity constraint for the decision variables which defines the quantity of freight (Tons) conveyed from each port by rail or/and road modes of transport to final transit country 


\subsection{Logistic Cost}

Logistic cost were used in this study as one of the parameters in the model computations. Such an approach aimed at evaluation the total costs borne by landlocked countries importers and the public at large for moving freight from main gateways to the final transit destination. In this respect, the logistics cost used in this study include port truck charges and railway charges based on extensive interviews with the main actors and operators in each corridor.

Logistic cost vary depending of infrastructure conditions, the Appendix 1 indicates the unit cost in ton per kilogram $(\mathrm{T} / \mathrm{Km})$ of freight transportation base West Africa borderless.

West Africa landlocked countries (WALLCs) are connected to sea port through several corridors. Each WALLC is linked with five main corridors to the main gateway of Cotonou, Lome, Tema, Abidjan and Dakar ports. Tables 1-3 show all corridors linking WALLC to sea and alternative mode of transport and corresponding total transport cost.

Table 1. Logistic cost of corridors linking Niger (Niamey) to sea ports.

\begin{tabular}{ccccc}
\hline Corridors & links & Transport \\
Mode & Cotonou-Parakou & Rail & $\begin{array}{c}\text { Distance } \\
(\mathrm{Km})\end{array}$ & $\begin{array}{c}\text { Associated } \\
\text { Transportation } \\
\text { Cost (USD) }\end{array}$ \\
\hline \multirow{2}{*}{ Cotonou to Niamey } & Parakou-Niamey & Road & 606 & 175.32 \\
Lome to Niamey & Lome-Atapkame & Rail & 162 & 190.98 \\
Tema Port to Niamey & Atapkame-Niamey & Road & 917 & 206.76 \\
Abidjan to Niamey & Tema-Niamey & Road & 1216 & 253.54 \\
& Obidjan-Ouagadougou & Rail & 1145 & \\
& Ouagadougou-Niamey & Road & 512 & 465.76 \\
\hline
\end{tabular}

Table 2. Logistic corridors linking Burkina Faso (Ouagadougou) to sea ports.

\begin{tabular}{|c|c|c|c|c|}
\hline Corridors & links & $\begin{array}{c}\text { Transport } \\
\text { Mode }\end{array}$ & Distance & $\begin{array}{c}\text { Associated } \\
\text { Transport } \\
\text { Cost }(\$)\end{array}$ \\
\hline \multirow{2}{*}{ Cotonou to Ouagadougou } & Cotonou-Parakou & Rail & 435 & \multirow{2}{*}{189.72} \\
\hline & Parakou-Ouagadougou & Road & 686 & \\
\hline \multirow{2}{*}{ Lome to Ouagadougou } & Lome-Atapkame & Rail & 162 & \multirow{2}{*}{168.48} \\
\hline & Atapkame-Ouagadougou & Road & 792 & \\
\hline Tema to Ouagadougou & Tema-Ouagadougou & Road & 1021 & 173.57 \\
\hline Abidjan to Ouagadougou & Abidjan-Ouagadougou & Rail & 1145 & 166.5 \\
\hline \multirow{2}{*}{ Dakar to Ouagadougou } & Dakar-Bamako & Rail & 1280 & \multirow{2}{*}{375.92} \\
\hline & Bamako-Ouagadougou & road & 876 & \\
\hline
\end{tabular}


Table 3. Logistic cost of corridors linking Mali (Bamako) to sea port.

\begin{tabular}{ccccc}
\hline \multicolumn{1}{c}{ Corridors } & links & $\begin{array}{c}\text { Transport } \\
\text { Mode }\end{array}$ & $\begin{array}{c}\text { Distance } \\
\text { Km }\end{array}$ & $\begin{array}{c}\text { Associated Transport } \\
\text { Cost (\$) }\end{array}$ \\
\hline \multirow{2}{*}{ Cotonou to Bamako } & Cotonou-Parakou & Rail & 435 & 347.94 \\
& Parakou-Bamako & Road & 1565 & 326.70 \\
& Lome-Atapkame & Rail & 162 & 267.41 \\
Lome to Bamako & Atapkame-Bamako & Road & 1671 & 179.88 \\
Tema to Bamako & Tema -Bamako & Road & 1573 & \\
Abidjan to Bamako & Abidjan-Ferke & Rail & 558 & 218.24 \\
\hline \multirow{2}{*}{ Dakar to Bamako } & Ferke-Bamako & Road & 604 & \\
\hline
\end{tabular}

\subsection{Model Implementation in Lingo}

We suppose that West Africa ECOWAS region has five main gateways of Dakar port, Abidjan port, Tema Port, Lome port and Cotonou port supplying tree transit landlocked countries namely Mali, Burkina Faso and Niger in West Africa and each LLCs has freight demand that must be satisfied.

We want to determine how many freight quantity to ship from each port to transit country so as to minimize the total shipping cost by optimizing an intermodal transport.

In solving model developed Lingo mathematical modeling language was used (Appendix 2).

\section{Results and Interpretations}

Under unimodal freight transportation the optimal route for transit to Mali, Burkina Faso and Niger are via respectively via Dakar port, Abidjan port and Cotonou port. Indeed Dakar port is Mali most important gateway (about 65\% of Mali transit traffic) is via Dakar; only $26 \%$ is via Abidjan port and the remain $9 \%$ to others main gateways of Cotonou port (5.2\%) Lome port (2.3\%) and Tema port (1.5\%).

Abidjan port is the most important gateway of Burkina Faso (40\%) followed by Lome port (31.32\%); Tema port (16.64\%) and Cotonou port (12.37\%).

Then Cotonou port is the optimal one for Niger (89.47\%) and the remain to the others ports (Table 4 and Figure 4).

By adopting rail-road intermodal transport, model results (Appendix 3) show that; the optimal route for freight transit to Burkina Faso changed Lome Port.

Cotonou port become the optimal and only one transit port for freight transportation to Niger.

The quantity of freight in transit from Abidjan port to Mali has also increased from $26 \%$ to $35 \%$ (Table 5 and Figure 5). 


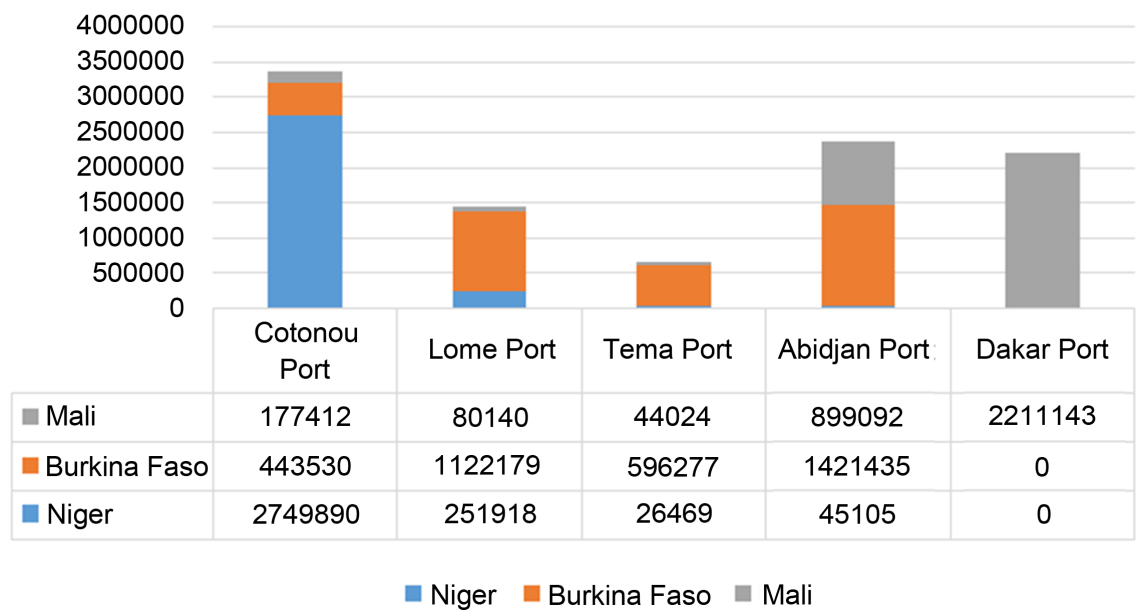

Figure 4. Unimodal freight quantity repartition by ports based on 2015 statistic.

\begin{tabular}{|c|c|c|c|c|c|}
\hline \multirow{2}{*}{$\begin{array}{l}4000000 \\
3500000\end{array}$} & & & \multicolumn{2}{|c|}{ rmodal Transport Freight Repartition } & \\
\hline & \multicolumn{5}{|c|}{3000000} \\
\hline \multicolumn{6}{|l|}{2500000} \\
\hline \multicolumn{6}{|l|}{2000000} \\
\hline \multicolumn{6}{|l|}{$\begin{array}{l}1500000 \\
1000000\end{array}$} \\
\hline $\begin{array}{r}1000000 \\
50000\end{array}$ & & & & & \\
\hline 0 & & & & & \\
\hline & $\begin{array}{l}\text { Cotonou } \\
\text { Port }\end{array}$ & Lome Port & Tema Port & Abidjan Port & Dakar Port \\
\hline Mali & 0 & 0 & 0 & 1140668 & 2211143 \\
\hline Burkina & 297459 & 1454237 & 666770 & 1164964 & 0 \\
\hline Niger & 3073382 & 0 & 0 & 0 & 0 \\
\hline
\end{tabular}

Figure 5. Intermodal optimization freight by port to transit countries, 2015.

Table 4. Unimodal freight quantity repartition by ports based on 2015 statistic.

\begin{tabular}{|c|c|c|c|c|c|c|c|}
\hline \multicolumn{8}{|c|}{ Unimodal Freight Quantity Repartition (Ton) } \\
\hline \multirow{2}{*}{ Ports } & \multicolumn{2}{|c|}{ Mali } & \multicolumn{2}{|c|}{ Burkina Faso } & \multicolumn{2}{|c|}{ Niger } & \multirow{2}{*}{$\begin{array}{l}\text { Total } \\
\text { (Ton) }\end{array}$} \\
\hline & Quantity & $(\%)$ & Quantity & $(\%)$ & Quantity & $(\%)$ & \\
\hline Cotonou & 177,412 & 5.2 & 443,530 & 12 & $2,749,890$ & 89.47 & $3,370,832$ \\
\hline Lome & 80,140 & 2.3 & $1,122,179$ & 31 & 251,918 & 8.2 & $1,454,237$ \\
\hline Tema & 44,024 & 1.5 & 596,277 & 17 & 26,469 & 0.89 & 666,770 \\
\hline Abidjan & 839,092 & 26 & $1,421,435$ & 40 & 45,105 & 1.47 & $2,305,632$ \\
\hline Dakar & $2,211,143$ & 65 & 0 & 0 & 0 & 0 & $2,211,143$ \\
\hline Total & $3,351,811$ & 100 & $3,583,421$ & 100 & $3,073,382$ & 100 & \\
\hline
\end{tabular}


Table 5. Intermodal optimization freight repartition by port to transit countries.

\begin{tabular}{cccccccc}
\hline \multicolumn{7}{c}{ Intermodal Freight Quantity Repartition (Ton). } \\
\hline \multirow{2}{*}{ Ports } & \multicolumn{2}{c}{ Mali } & \multicolumn{2}{c}{ Burkina Faso } & \multicolumn{2}{c}{ Niger } & \multirow{2}{*}{ Total } \\
\cline { 2 - 6 } & Quantity & $(\%)$ & Quantity & $(\%)$ & Quantity & $(\%)$ & (Ton) \\
\hline Cotonou & 0 & & 297,459 & 8.3 & $3,073,382$ & 100 & $3,370,832$ \\
Lome & 0 & & $1,454,237$ & 40.58 & 0 & 0 & $1,454,237$ \\
Tema & 0 & & 666,770 & 18.60 & 0 & 0 & 666,770 \\
Abidjan & $1,140,668$ & 35 & $1,164,964$ & & 0 & 0 & $2,305,632$ \\
Dakar & $2,211,143$ & 65 & 0 & 32.50 & 0 & 0 & $2,211,143$ \\
Total & $3,351,811$ & 100 & $3,583,421$ & 100 & $3,073,382$ & 100 & \\
\hline
\end{tabular}

\section{Conclusions}

The objective in this study was the intermodal routing problem of regional freight transportation in West Africa, which can be defined as the problem of determining the freight flow quantity, the transportation mode in each transit corridor while satisfying the freight demand at each West Africa transit country by adopting intermodal freight optimization.

Under the current unimodal freight transportation the optimal route for transit to Mali is via Dakar port (65\%), followed by Abidjan port (26\%).The optimal port to Burkina Faso is Abidjan port (40\%), followed by Lome port (31\%), Tema port $(17 \%)$ and Cotonou port (12\%). The optimal port to Niger is Cotonou (89\%), followed by Lome port (8.1\%).

By adopting rail-road intermodal transport, the optimization results show that: the optimal route for freight transit to Burkina Faso changed to Lome Port (40.58\%). Cotonou port becomes the optimal and only one transit port for freight transit to Niger (100\%). And the quantity of freight in transit from Abidjan port to Mali has also increased from $26 \%$ to $35 \%$.

This clearly shows that port oriented freight logistics in west Africa ECOWAS region do not flow along optimal path and such incur longer time and higher logistics cost than is geographically necessary. Evident, the region misses out on the potentialities of intermodality.

\section{Conflicts of Interest}

The author declares no conflicts of interest regarding the publication of this paper.

\section{References}

[1] Acciaro, M., Bardi, A., Cusano, M.I., Ferrari, C. and Tei, A. (2017) Contested Port Hinterlands: An Empirical Survey on Adriatic Seaports. Case Studies on Transport Policy, 5, 342-350. https://doi.org/10.1016/j.cstp.2017.03.006

[2] Meersman, H., Van De Voorde, E. and Vanelslander, T. (2009) Future Challenges for Port and Shipping Sector. Informa, London.

[3] Tongzon, H. (2009) Port Choice and Freight Forwarders. Transport Research, 45, 
186-195. https://doi.org/10.1016/j.tre.2008.02.004

[4] Roso, V., Woxenius, J. and Lumsden, K. (2009) The Dry Port Concept: Connecting Container Seaport with the Hinterland. Journal of Transport Economy, 17, 338-345. https://doi.org/10.1016/j.jtrangeo.2008.10.008

[5] La, M. and Gu, L. (2013) Port Hinterland Intermodal Container Flow Optimization with Green Concerns: A Literature Review And Research Agenda. International Journal of Shipping and Transport Logistics, 5, 257-281. https://doi.org/10.1504/IJSTL.2013.054190

[6] Rodrigue, K. and Notteboom, G. (2010) Comparative North American and European Gateway Logistics: The Regionalism of Freight Distribution. Journal of Transport, 18, 497-507. https://doi.org/10.1016/j.jtrangeo.2010.03.006

[7] Wang, C.X. (2008) Operation of Hub and Poke Two Stage Logistic Network in Regional Port Clusters. System Engineering-Theory \& Practice, 28, 152-158. https://doi.org/10.1016/S1874-8651(09)60040-5

[8] Gen, M. and Cheng, L. (2008) Network Models and Optimization, Multi-Objective Genetic Algorithm Approach. Spring Verlag, Berlin.

[9] Goetschalckx, F., et al. (2005) A Stochastic Programming Approach for Supply Chain Network Design under Uncertainty. European Journal of Operational Research, 167, 96-115. https://doi.org/10.1016/j.ejor.2004.01.046

[10] Ahuja, M. and Orlin, D. (1993) Network Flows, Theory, Algorithms and Application.

[11] Winston, M. (2003) Operation Research Application and Algorithm. 4th Edition, Cengage Learning, New York.

[12] Yildirimi, M.B. (2008) Network Optimization. In: Ravindran, R.A., Ed., Operation Research and Management Science Handbook, Taylor \& Francis Group, London.

[13] Crainic, D. (2007) Intermodal Transport. Handbooks in Operation Research and Management Science, 14, 467-537. https://doi.org/10.1016/S0927-0507(06)14008-6

[14] Sciomachen, A. and Liu, M. (2009) Operation Research Methods in Maritime Transport and Freight Logistics. Maritime Economic and Logistics, 11, 1-6. https://doi.org/10.1057/mel.2008.18

[15] Wilson, W. and Benson, S. (2010) Analysis of Container Flows, Word Trade, US Waterborne and Commerce and Rail Shipment in North America Markets. Report North Dakota State.

[16] Leung, W. and Lai, E. (2002) An Optimization Model for Cross-Border Logistic Problem Case in Hong Kong. Computer and Industrial Engineering, 43, 393-405. https://doi.org/10.1016/S0360-8352(02)00081-5

[17] Ubogu, A. and Mamman, G. (2011) Port Hinterland Trucking Constrains in Nigeria. Journal of Transport Geography, 19, 106-114. https://doi.org/10.1016/j.jtrangeo.2009.09.001

[18] Goetschalckx, F., et al. (2002) Modeling and Design of Global Logistics Systems: A Review of Integrated Strategic and Tactical Models and Design Algorithms. European Journal of Operational Research, 143, 1-18. https://doi.org/10.1016/S0377-2217(02)00142-X

[19] Daskin, M. (2001) Capacitated Facility Location Network Design Problem. European Journal of Operational Research, 129, 481-495. https://doi.org/10.1016/S0377-2217(99)00464-6 
Appendix 1: Freight Transport Cost Use for Model Computation (Ton/Kilometer)

\begin{tabular}{ccc}
\hline Country & Transport cost-road (US\$ ton $\mathbf{k m})$ & Transport cost-rail (US\$ ton $\mathbf{k m})$ \\
\hline Senegal & 0.20 & 0.18 \\
Cote d'Ivoire & 0.17 & 0.15 \\
Ghana & 0.17 & N/A \\
Togo & 0.18 & 0.16 \\
Benin & 0.18 & 0.16 \\
\hline
\end{tabular}

\section{Appendix 2: Lingo Optimization Model Implementation}

\section{MODEL:}

!A 5 Ports 3 Transit Countries Transportation Optimization Problem; SETS:

Ports: Freight Quantity;

Transit Countries: Demand;

Links (Ports, Transit Countries): Cost, Quantity;

\section{ENDSETS}

!Here is the data;

DATA:

!set members;

Ports = Dakar (P1) Abidjan (P2) Tema (P3) Lome (P4) Cotonou (P5);

Transit Countries = Bamako (D1) Ouagadougou (D2) Niamey (D3);

!attribute values;

Quantity;

Demand;

Cost;

End data

!The objective;

$\operatorname{Min}=@ \operatorname{Sum}(\operatorname{Links}(\mathrm{I}, \mathrm{J})$ :

Cost $(\mathrm{I}, \mathrm{J}){ }^{\star}$ Quantity $\left.(\mathrm{I}, \mathrm{J})\right)$;

!The demand constraints;

@For (TransitCountries (J):

@Sum (Ports (I): Quantity (I, J)) = Demand (J));

!The capacity constraints;

@For (Ports (I):

@Sum (TransitCountries (J): Quantity (I, J)) <= Quantity (I));

End

Appendix 3: West Africa Freight Flow 0ptimization Results

Global optimal solution found.

Objective value: $0.1837708 \mathrm{E}+10$

Infeasibilities: 0.000000

Total solver iterations: 8 


\begin{tabular}{|c|c|c|}
\hline Variable & Value & Reduced Cost \\
\hline Capacity (Dakar) & $2,211,143$ & 0.000000 \\
\hline Capacity (Abidjan) & $2,305,632$ & 0.000000 \\
\hline Capacity (Tema) & $666,770.0$ & 0.000000 \\
\hline Capacity (Lome) & $1,454,237$ & 0.000000 \\
\hline Capacity (Cotonou) & $3,370,832$ & 0.000000 \\
\hline Demand (Mali) & $3,351,811$ & 0.000000 \\
\hline Demand (Burkina) & $3,583,421$ & 0.000000 \\
\hline Demand (Niger) & $3,073,382$ & 0.000000 \\
\hline Cost (P1, D1) & 218.2400 & 0.000000 \\
\hline Cost (P1, D2) & 375.9200 & 0.000000 \\
\hline Cost (P1, D3) & 465.7600 & 0.000000 \\
\hline $\operatorname{Cos}(\mathrm{P} 2, \mathrm{D} 1)$ & 179.8800 & 0.000000 \\
\hline Cost (P2, D2) & 166.5000 & 0.000000 \\
\hline Cost (P2, D3) & 253.5400 & 0.000000 \\
\hline Cost (P3, D1) & 267.4100 & 0.000000 \\
\hline Cost (P3, D2) & 173.5700 & 0.000000 \\
\hline Cost (P3, D3) & 206.7600 & 0.000000 \\
\hline Cost (P4, D1) & 326.7000 & 0.000000 \\
\hline Cost (P4, D2) & 168.4800 & 0.000000 \\
\hline Cost (P4, D3) & 190.9800 & 0.000000 \\
\hline Cost (P5, D1) & 347.9400 & 0.000000 \\
\hline Cost (P5, D2) & 189.7200 & 0.000000 \\
\hline Cost (P5, D3) & 175.3200 & 0.000000 \\
\hline Quantity (P1, D1) & $2,211,143$ & 0.000000 \\
\hline Quantity (P1, D2) & 0.000000 & 171.0600 \\
\hline Quantity (P1, D3) & 0.000000 & 275.3000 \\
\hline Quantity (P2, D1) & $1,140,668$ & 0.000000 \\
\hline Quantity (P2, V2) & $1,164,964$ & 0.000000 \\
\hline Quantity (P2, D3) & 0.000000 & 101.4400 \\
\hline Quantity (P3, D1) & 0.000000 & 80.46000 \\
\hline Quantity (P3, D2) & $666,770.0$ & 0.000000 \\
\hline Quantity (P3, D3) & 0.000000 & 47.59000 \\
\hline Quantity (P4, D1) & 0.000000 & 144.8400 \\
\hline Quantity (P4, D2) & $1,454,237$ & 0.000000 \\
\hline Quantity (P4, D3) & 0.000000 & 36.90000 \\
\hline Quantity (P5, D1) & 0.000000 & 144.8400 \\
\hline Quantity (P5, D2) & $297,450.0$ & 0.000000 \\
\hline Quantity (P5, D3) & $3,073,382$ & 0.000000 \\
\hline Row & Slack or Surplus & Dual Price \\
\hline 1 & $0.1837708 \mathrm{E}+10$ & -1.000000 \\
\hline 2 & 0.000000 & -218.2400 \\
\hline 3 & 0.000000 & -204.8600 \\
\hline
\end{tabular}


$-190.4600$

0.000000

36.38000

15.14000 